\title{
Effect of indomethacin on egg transport and pregnancy in the rabbit
}

\author{
A. A. El-Banna, ${ }^{*}$ B. Sacher and E. Schilling \\ Max-Planck-Institut für Tierzucht und Tierernährung, \\ 3051 Mariensee, West Germany
}

\begin{abstract}
Summary. Treatment of rabbits with indomethacin $(10 \mathrm{mg} / \mathrm{kg} /$ day $) 48 \mathrm{hr}$ before mating, and with $20 \mathrm{mg} / \mathrm{kg}$ at $12 \mathrm{hr}$ followed by $8 \mathrm{mg} / \mathrm{kg}$ at 48,72 or $96 \mathrm{hr}$ after mating did not affect the rate of egg transport through the oviduct. Indomethacin treatment at the time of implantation interfered with pregnancy and caused degeneration and resorption of embryos. These results suggest that inhibition of prostaglandin synthesis does not directly affect egg transport, but that prostaglandin appears to be required for the retention of implanted embryos.
\end{abstract}

\section{Introduction}

Spilman \& Harper (1973) reported that prostaglandins (PGs) of the E and F series are mutually antagonistic in their effects on oviducal muscle activity. They suggested that the $F$ prostaglandins may act to retain the embryos in the oviduct by virtue of their occlusive action and that the E prostaglandins may allow the embryos to pass into the uterus by abolishing tubal occlusion. Sandberg, Ingelmann-Sundberg \& Ryden $(1963,1964)$ reported that PGE-1 and PGE-2 cause contraction of the most proximal end of the human oviduct in vitro, while the distal part becomes relaxed. Prostaglandin E-3 causes relaxation of all parts of the oviduct, while PGF-1 $\alpha$ and PGF-2 $\alpha$ cause contraction (Sandberg et al., 1964, 1965). Brundin (1965) reported that PGE-1 administered intravenously caused a relaxation of the isthmic circular muscle in the rabbit, and Ramwell, Shaw \& Jessup (1969) found that PGE-1 reduced the motility of bovine and rabbit oviducts in vitro. Levy \& Lindner (1971) stated that PGE-1 reduced, and PGF-2 $\alpha$ increased, the contractility of rabbit oviducts perfused in vivo.

The present experiments were undertaken to determine whether normal egg transport would be affected by treatment with indomethacin, a potent inhibitor of prostaglandin synthesis, and to determine the effect of such treatment on subsequent pregnancy.

\section{Materials and Methods}

A total of 113 mature female rabbits of mixed breed, weighing $3 \cdot 5-4 \cdot 4 \mathrm{~kg}$, were used. Indomethacin was administered either intravenously (i.v.) as a $50 \mathrm{mg} / \mathrm{ml}$ suspension in $0 \cdot 1 \mathrm{M}$-phosphate buffer (pH 8.0), or subcutaneously (s.c.) as a $70 \mathrm{mg} / \mathrm{ml}$ suspension in sesame oil.

\section{Egg transport}

Forty rabbits were allotted to two groups, one of which received i.v. injections, and the other s.c. injections. Pretreatment with $10 \mathrm{mg}$ indomethacin/ $\mathrm{kg} /$ day was started 2 days before mating. Each doe was mated to two fertile bucks and was treated i.v. with 50 i.u. HCG (Primogonyl: Schering). At $12 \mathrm{hr}$ after mating, each doe received $20 \mathrm{mg}$ indomethacin $/ \mathrm{kg}$, followed by $8 \mathrm{mg} / \mathrm{kg}$ every $12 \mathrm{hr}$ thereafter until the time of autopsy. Control animals were injected with the same volume of the

* Present address: Human Reproduction Research Unit, Department of Obstetrics and Gynecology, Faculty of Medicine, Al-Azhar University, Cairo, Egypt. 
vehicle. Animals were killed by stunning and exsanguination 48,72 or $96 \mathrm{hr}$ after mating, and the oviducts and uteri were removed and dissected free of fat. Each oviduct was divided into 8 equal segments, and the segment closest to the fimbria was designated Segment 1. Each segment was flushed from both ends with Ringer solution into concave dishes, and the uterine horns were also flushed separately. The number of eggs in the flushings from each segment was determined microscopically.

\section{Pregnancy}

Each of 73 does was mated to two fertile bucks and received an i.v. injection of 50 i.u. HCG. The does were then allotted to four treatment groups as follows: Group 1: indomethacin was administered i.v. $12 \mathrm{hr}$ after mating $(20 \mathrm{mg} / \mathrm{kg})$ and then every $12 \mathrm{hr}(8 \mathrm{mg} / \mathrm{kg})$ until 9 days after mating; Group 2: indomethacin was administered s.c. $12 \mathrm{hr}$ after mating $(20 \mathrm{mg} / \mathrm{kg})$ and then every $12 \mathrm{hr}$ $(8 \mathrm{mg} / \mathrm{kg})$ until 9 days after mating; Group 3: indomethacin was administered s.c. $12 \mathrm{hr}$ after mating $(20 \mathrm{mg} / \mathrm{kg})$ and then every $12 \mathrm{hr}(8 \mathrm{mg} / \mathrm{kg})$ until 5 days after mating; Group 4: starting on Day 5 after mating, indomethacin was administered s.c. every $12 \mathrm{hr}(8 \mathrm{mg} / \mathrm{kg})$ until 9 days after mating.

In all groups, control animals were injected with the same volume of the vehicle.

On the 9th day after mating the does were either killed or subjected to laparotomy through a midline incision. The reproductive tracts were exposed and the number of corpora lutea on each ovary as well as the number and size of the implantation sites in each uterine horn were measured.

\section{Results}

Since no differences in egg transport were observed between the animals injected i.v. and those injected s.c., the results from the two groups were pooled (Table 1). Egg transport and distribution in the treated animals were not significantly different from those in the controls. No differences were observed between the treated and the control groups in the number of ovulation points or in the number of eggs recovered. In this experiment, an average of $19 \%$ of the eggs recovered were unfertilized.

As shown in Table 2, the majority of the implantation sites in the rabbits in Groups 1, 2 and 4 were resorbed by Day 9 , but when indomethacin treatment was stopped at Day 5 after mating (Group 3), almost all the implantation sites on Day 9 were viable.

The mean number of implantation sites was smaller in Groups 1, 2 and 4 than that in Group 3 and in the control groups. No resorbing sites were observed in any of the control groups.

No toxic effects (changes in eating habits or weight) were observed as a result of the indomethacin treatment.

\section{Discussion}

Indomethacin treatment in this study did not affect oviducal egg transport. Since plasma and tissue levels of prostaglandins were not measured during the treatment period, it is not possible to confirm that the absence of prostaglandins would interfere with the process of egg transport. Indomethacin has, however, been reported to be a potent inhibitor of prostaglandin synthesis in several tissues and in several species (Collier \& Flower, 1971; Ferreira, Moncada \& Vane, 1971; Vane, 1971; Orczyk \& Behrman, 1972; Skarnes \& Harper, 1972).

One clear effect of indomethacin was its interference with normal pregnancy. Although implantation was not totally prevented, almost all embryos were found to be degenerating at Day 9 of pregnancy when indomethacin was injected around the time of implantation.

O'Grady, Caldwell, Auletta \& Speroff (1972) observed the same antifertility effect of indomethacin in rabbits treated daily from the day of mating until 21-28 days of pregnancy. More recently, Saksena \& Harper (1974) observed fetal resorption on Day 12 following treatment with 


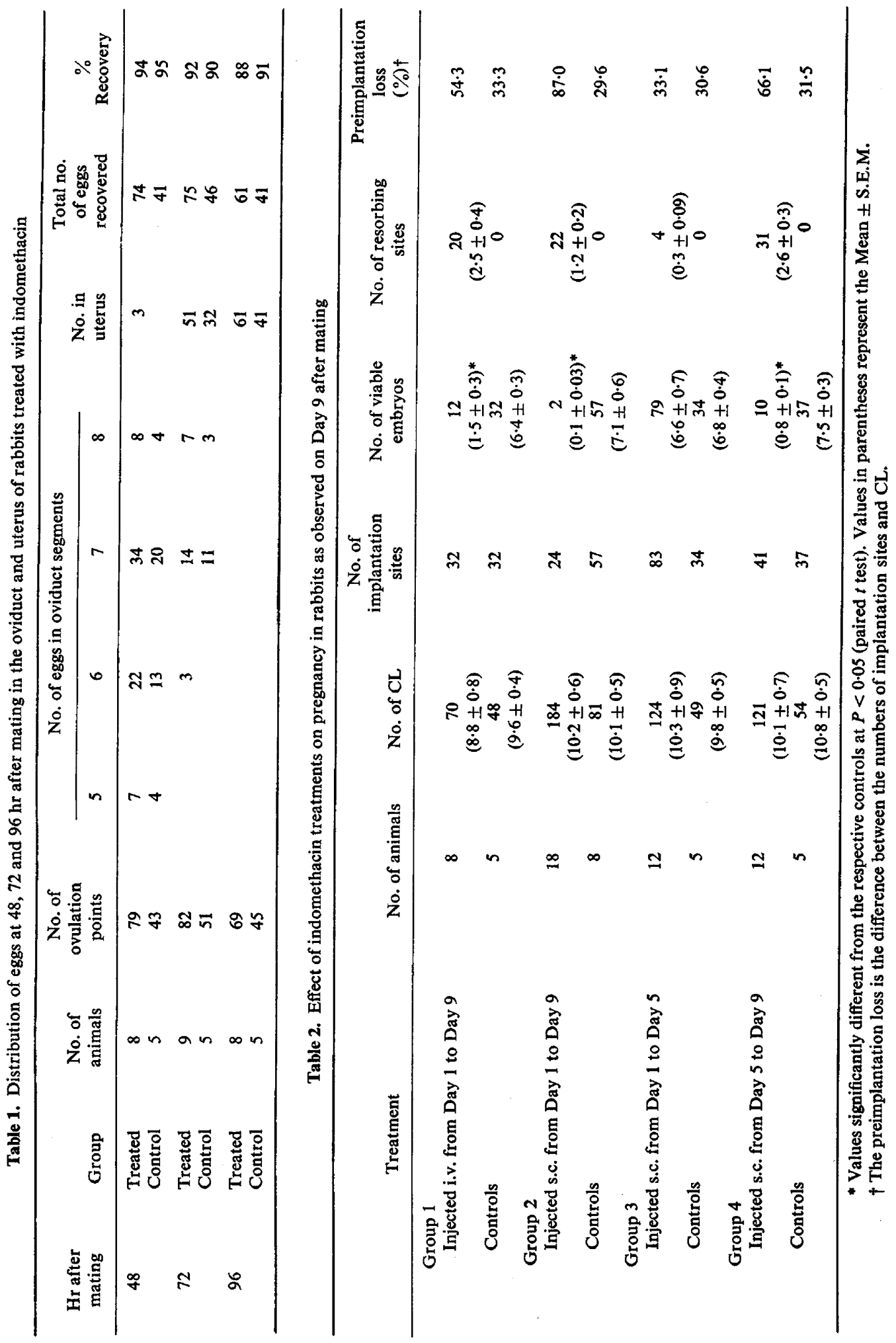


indomethacin from Days 3 to 6 of pregnancy. No effect on pregnancy was observed in the present study when indomethacin treatment was stopped at Day 5 after mating. This may suggest that the stage in the rabbit which is most sensitive to indomethacin occurs just before implantation. It may also suggest that the presence of prostaglandins is required for normal embryonic development around the time of implantation (Saksena \& Harper, 1974).

The number and appearance of corpora lutea at Day 9 of pregnancy were normal in the treated animals, and histological examination revealed no changes except that the size of the lutein cells was larger than in the controls. It has been reported that indomethacin treatment results in an increase in progestin secretion in the rabbit (Grinwich, Kennedy \& Armstrong, 1972), but examination of histological sections from the treated uteri in this study did not reveal any obvious related changes.

The low level of fertilization could be the reason for the high preimplantation loss found in the controls. The bucks used for mating in this experiment (a total of eight) were extensively used, and this could have affected fertilization.

In conclusion, the results of this study demonstrate that indomethacin does not interfere with the process of egg transport, but can disturb pregnancy in the rabbit, suggesting that although prostaglandins are not directly involved in controlling egg transport they could be important in supporting the newly implanted embryos.

Indomethacin was supplied most generously by Sharp and Dohme GmbH., Munich, West Germany. One of us (A.A.E.-B.) is an Alexander von Humboldt Fellow.

\section{References}

BRUNDIN, J. (1965) Distribution and function of adrenergic nerves in the rabbit Fallopian tube. Acta physiol. scand. 66, Suppl. 259, 40-41.

Collier, J.G. \& Flower, R.J. (1971) Effect of aspirin on human seminal prostaglandins. Lancet ii, $852-$ 853.

Ferreira, S.H., Moncada, S. \& Vane, J.R. (1971) Indomethacin and aspirin abolish prostaglandin release from the spleen. Nature, New Biol. 231, 237-239.

Grinwich, D.L., Kennedy, T.G. \& Armstrong, D.T. (1972) Dissociation of ovulatory and steroidogenic actions of luteinizing hormone in rabbits with indomethacin, an inhibitor of prostaglandin biosynthesis. Prostaglandins 1, 89-96.

LEVY, B. \& LINDNER, H.R. (1971) Selective blockade of the vasopressor response to prostaglandin $F_{2 \alpha}$ in the anesthetized rabbit. Br.J.Pharmac. Chemother. 43, 236-241.

O'Grady, J.P., Caldwel.l, B.V., Auletta, F.J. SPEROFF, L. (1972) The effects of an inhibitor of prostaglandin synthesis (indomethacin) on ovulation, pregnancy, and pseudopregnancy in rabbit. Prostaglandins 1, 97-106.

OrczyK, G.P. \& Behrman, H.R. (1972) Ovulation blockade by aspirin or indomethacin-in vivo evidence for a role of prostaglandin in gonadotrophin secretion. Prostaglandins 1, 3-20.

Ramwell, P.W., Shaw, J.E. \& Jessup, S.J. (1969)
Follicular fluid kinin and its action on Fallopian tube. Endocrinology 84, 931-939.

SAKSENA, S.K. \& HARPER, M.J.K. (1974) Prostaglandinmediated action of intrauterine devices: F-prostaglandins in the uterine horns of pregnant rabbits with unilateral intrauterine devices. Fert. Steril. 25, 121-126.

SANdberG, F., Ingelmann-SundberG, A. \& Ryden, G. (1963) The effect of prostaglandin $E_{1}$ on the human uterus and the fallopian tubes in vitro. Acta obstet. gynec. scand. 42, 269-278.

SANDberG, F., INGelmanN-SundberG, A. \& RXDEN, G. (1964) The effect of prostaglandin $E_{2}$ and $E_{3}$ on the human uterus and fallopian tubes in vitro. Acta obstet. gynec, scand. 43, 95-103.

SANDBERG, F., INGelmanN-SundBerg, A. \& RYden, G. (1965) The effect of prostaglandin $F_{1 \alpha}, B_{1 \beta}$, $F_{2 \alpha}$ and $F_{2 \beta}$ on the human uterus and the fallopian tubes in vitro. Acta obstet. gynec, scand. 44, 585-594.

SKaRNes, R.C. \& HaRPER, M.J.K. (1972) Relationship between endotoxin-induced abortion and the synthesis of prostaglandin F. Prostaglandins 1, 191-204.

SPILMAN, C.H. \& HARPER, M.J.K. (1973) Effects of prostaglandins on oviduct motility in estrous rabbits. Biol. Reprod. 9, 36-45.

VANE, J.R. (1971) Inhibition of prostaglandin synthesis as a mechanism of action for aspirin-like drugs. Nature, New Biol. 231, 232-235. 